Review began 10/24/2021 Review ended 10/31/2021 Published 11/05/2021

๑) Copyright 2021

Kaeley et al. This is an open access article distributed under the terms of the Creative Commons Attribution License CC-BY 4.0. which permits unrestricted use, distribution, and reproduction in any medium, provided the original author and source are credited.

\section{Paraquat Poisoning Associated With Daisley Barton Syndrome: A Case Report}

\author{
Nidhi Kaeley ${ }^{1}$, Hari Prasad Jr. ${ }^{1}$, Ankita Kabi ${ }^{2}$, Alok Raj ${ }^{1}$, Archana Bairwa ${ }^{1}$ \\ 1. Emergency Medicine, All India Institute of Medical Sciences, Rishikesh, Rishikesh, IND 2. Emergency Medicine \\ (Anaesthesiology), All India Institute of Medical Sciences, Rishikesh, Rishikesh, IND
}

Corresponding author: Hari Prasad Jr., hariprasad007007007@gmail.com

\begin{abstract}
Pesticides include insecticides, herbicides, and rodenticides. Pesticide poisoning can be intentional, accidental, or occupational. Around 385 million cases of unintentional acute pesticide poisoning occur annually worldwide, with approximately 11,000 fatalities. Herbicides are used to kill weeds and can include chlorophenoxy compounds, bipyridyls, urea-substituted herbicides, organophosphates, and glyphosate. Paraquat is a bipyridyl nonselective contact herbicide with high mortality rates upon exposure in humans. Paraquat poisoning causes acute lung injury, rarely leading to pneumothorax and pneumomediastinum, referred to as Daisley Barton Syndrome. We report a case of a 22 -year-old female from Uttarakhand, India, who accidentally ingested paraquat. She was initially asymptomatic, but later developed lung, liver, and kidney injuries as well as pneumomediastinum and pneumothorax.
\end{abstract}

Categories: Emergency Medicine

Keywords: case report, pesticides, pneumothorax, pneumomediastinum, paraquat

\section{Introduction}

Paraquat poisoning has been reported worldwide, but only a few cases have been reported in India [1]. Paraquat (1,1'-dimethyl-4,4'-dipyridylium) is a toxic, corrosive liquid with a strong odor [2]. After ingestion, it mainly enters the lungs, liver, and kidneys [3]. The principal affected organ is the lungs [1]. Besides local corrosive damage to the oral cavity and gastrointestinal mucosa, paraquat also causes metabolic acidosis, acute kidney and liver injury, pulmonary fibrosis, and acute respiratory distress [4]. Very rarely, it can cause spontaneous pneumothorax or pneumomediastinum [5]. Paraquat-induced acute lung injuries, namely pneumothorax and pneumomediastinum, are collectively referred to as Daisley Barton Syndrome [6]. We present a case of Daisley Barton Syndrome in a 22 -year-old female after the ingestion of paraquat.

\section{Case Presentation}

A 22-year-old female with no known comorbidities or history of taking medications presented to the emergency department of a tertiary care institute in Uttarakhand after having ingested $100 \mathrm{~mL}$ paraquatcontaminated water from her farmyard. Upon admission, she reported a history of blue-colored vomiting and dizziness and was immediately taken to the local hospital. Gastric lavage was not performed because of the corrosive nature of the poison. The patient was admitted there and discharged after two days. On day four after ingestion, she started experiencing burning pain in her upper and lower limbs, which worsened at night and disturbed her sleep. The patient complained of dyspnea on exertion for one day, which was Modified Medical Research Council (MMRC) Grade II that worsened to Grade III. It was not associated with cough, hemoptysis, chest pain, or orthopnea. She also complained of yellowish discoloration of the eyes, oral ulcers, and odynophagia associated with solids more than liquids. Due to the patient's symptoms, she was admitted to the local hospital's intensive care unit (ICU). During hospitalization, her dyspnea exaggerated to MMRC grade IV. Due to the requirement of ICU support, she was referred to a tertiary care institute in Uttarakhand on Day eight.

On examination, the patient was conscious. Her vital signs were as follows: Glasgow Coma Scale: E4V5M6, heart rate 112 beats per minute, oxygen saturation $60 \%$ in room air and $88 \%$ with 10 -L oxygen facemask, blood pressure 108/78 $\mathrm{mmHg}$, and respiratory rate 32 breaths per minute. Pallor and icterus were present on general examination. Local examination of the oral cavity revealed multiple yellowish plaques present over the tongue, buccal mucosa, and posterior wall of the pharynx. Respiratory system examination showed bilateral crepitations in the infraaxillary regions. Other system examinations were normal.

Laboratory investigations revealed anemia with neutrophilic leukocytosis, hyperbilirubinemia, transaminitis, elevated urea, and elevated creatinine, as shown in Table 1. 


\section{Cureus}

\begin{tabular}{|c|c|c|}
\hline Parameters & Results & Reference range \\
\hline Hemoglobin & $9.6 \mathrm{~g} / \mathrm{dL}(5.96 \mathrm{mmol} / \mathrm{L})$ & $12-15 \mathrm{~g} / \mathrm{dL}(7.45-9.31 \mathrm{mmol} / \mathrm{L})$ \\
\hline Red Blood Cell Count (RBC) & $2.66 \times 10^{6} / \mathrm{mcL}\left(2.66 \times 10^{12} / \mathrm{L}\right)$ & $3.8-5.2 \times 10^{6} / \mathrm{mcL}\left(3.8-5.2 \times 10^{12} / \mathrm{L}\right)$ \\
\hline White Blood Cell Count(WBC) & $16.09 \times 10^{3} / \mathrm{mcL}\left(16.09 \times 10^{9} / \mathrm{L}\right)$ & $4-11 \times 10^{3} / \mathrm{mcL}\left(4-11 \times 10^{9} / \mathrm{L}\right)$ \\
\hline Platelets & $216 \times 10^{3} / \mathrm{mcL}\left(216 \times 10^{9} / \mathrm{L}\right)$ & $150-400 \times 10^{3} / \mathrm{mcL}\left(150-400 \times 10^{9} / \mathrm{L}\right)$ \\
\hline Total bilirubin & $7.69 \mathrm{mg} / \mathrm{dL}(131.5 \mu \mathrm{mol} / \mathrm{L})$ & $0.3-1.2 \mathrm{mg} / \mathrm{dL}(5.13-20.52 \mu \mathrm{mol} / \mathrm{L})$ \\
\hline Direct bilirubin & $5.66 \mathrm{mg} / \mathrm{dL}(96.79 \mu \mathrm{mol} / \mathrm{L})$ & $0-0.2 \mathrm{mg} / \mathrm{dL}(0-3.42 \mu \mathrm{mol} / \mathrm{L})$ \\
\hline Alanine aminotransferase (ALT) & 77 U/L (1.28 $\mu \mathrm{kat} / \mathrm{L})$ & $0-35 \mathrm{U} / \mathrm{L}(0-0.58 \mu \mathrm{kat} / \mathrm{L})$ \\
\hline Aspartate aminotransferase (AST) & $83 \mathrm{U} / \mathrm{L}(1.38 \mu \mathrm{kat} / \mathrm{L})$ & $0-35 \mathrm{U} / \mathrm{L}(0-0.58 \mu \mathrm{kat} / \mathrm{L})$ \\
\hline Alkaline phosphatase (ALP) & $562 \mathrm{U} / \mathrm{L}(9.33 \mu \mathrm{kat} / \mathrm{L})$ & 30-120 U/L (0.5-2 $\mu \mathrm{kat} / \mathrm{L})$ \\
\hline Gamma Glutamyl Transpeptidase (GGT) & 2943 U/L (49.06 $\mu \mathrm{kat} / \mathrm{L})$ & $0-38 \mathrm{U} / \mathrm{L}(0-0.63 \mu \mathrm{kat} / \mathrm{L})$ \\
\hline Serum Albumin & $3.13 \mathrm{~g} / \mathrm{dL}(31.3 \mathrm{~g} / \mathrm{L})$ & $3.5-5.2 \mathrm{~g} / \mathrm{dL}(35-52 \mathrm{~g} / \mathrm{L})$ \\
\hline Urea & $181 \mathrm{mg} / \mathrm{dL}(30.13 \mathrm{mmol} / \mathrm{L})$ & $17-43 \mathrm{mg} / \mathrm{dL}(2.83-7.15 \mathrm{mmol} / \mathrm{L})$ \\
\hline Creatinine & $6.16 \mathrm{mg} / \mathrm{dL}(544.67 \mu \mathrm{mol} / \mathrm{L})$ & $0.55-1.02 \mathrm{mg} / \mathrm{dL}(48.63-90.19 \mu \mathrm{mol} / \mathrm{L})$ \\
\hline Sodium & $138 \mathrm{mEq} / \mathrm{L}(138 \mathrm{mmol} / \mathrm{L})$ & 136-146 mEq/L (136-146 mmol/L) \\
\hline Potassium & $3.4 \mathrm{mEq} / \mathrm{L}(3.4 \mathrm{mmol} / \mathrm{L})$ & 3.5-5.1 mEq/L (3.5-5.1 mmol/L) \\
\hline Calcium & $8.1 \mathrm{mg} / \mathrm{dL}(2.02 \mathrm{mmol} / \mathrm{L})$ & $8.8-10.6 \mathrm{mg} / \mathrm{dL}(2.2-2.64 \mathrm{mmol} / \mathrm{L})$ \\
\hline
\end{tabular}

\section{TABLE 1: Blood test results}

ALT, Alanine aminotransferase; AST, Aspartate aminotransferase; ALP, Alkaline phosphatase; GGT, Gamma Glutamyl Transpeptidase

Initial arterial blood gas (ABG) revealed respiratory alkalosis with adequate compensation, as shown in Table 2 .

\begin{tabular}{|c|c|c|c|c|c|}
\hline $\begin{array}{l}\text { Arterial Blood Gas (ABG) } \\
\text { parameters }\end{array}$ & $\begin{array}{l}\text { At the time of } \\
\text { admission }\end{array}$ & $\begin{array}{l}12 \text { hours after } \\
\text { admission }\end{array}$ & $\begin{array}{l}\text { Day } 2 \text { of } \\
\text { admission }\end{array}$ & $\begin{array}{l}\text { Day } 8 \text { of } \\
\text { admission }\end{array}$ & $\begin{array}{l}\text { Reference } \\
\text { range }\end{array}$ \\
\hline $\mathrm{pH}$ & 7.524 & 7.469 & 7.234 & 7.213 & 7.35-7.45 \\
\hline pCO2 & $26.2 \mathrm{mmHg}$ & $32.4 \mathrm{mmHg}$ & $54.2 \mathrm{mmHg}$ & $60.9 \mathrm{mmHg}$ & $35-45 \mathrm{mmHg}$ \\
\hline $\mathrm{HCO} 3$ & $21.8 \mathrm{mmol} / \mathrm{L}$ & $23.7 \mathrm{mmol} / \mathrm{L}$ & $28.6 \mathrm{mmol} / \mathrm{L}$ & $24.1 \mathrm{mmol} / \mathrm{L}$ & $22-26 \mathrm{mmol} / \mathrm{L}$ \\
\hline
\end{tabular}

\section{TABLE 2: Arterial Blood Gas results on different days}

ABG, Arterial Blood Gas

Chest radiograph revealed left lower lobe haziness, enhanced bronchovascular markings, and multiple patchy consolidations, as shown in Figure 1. 


\section{Cureus}

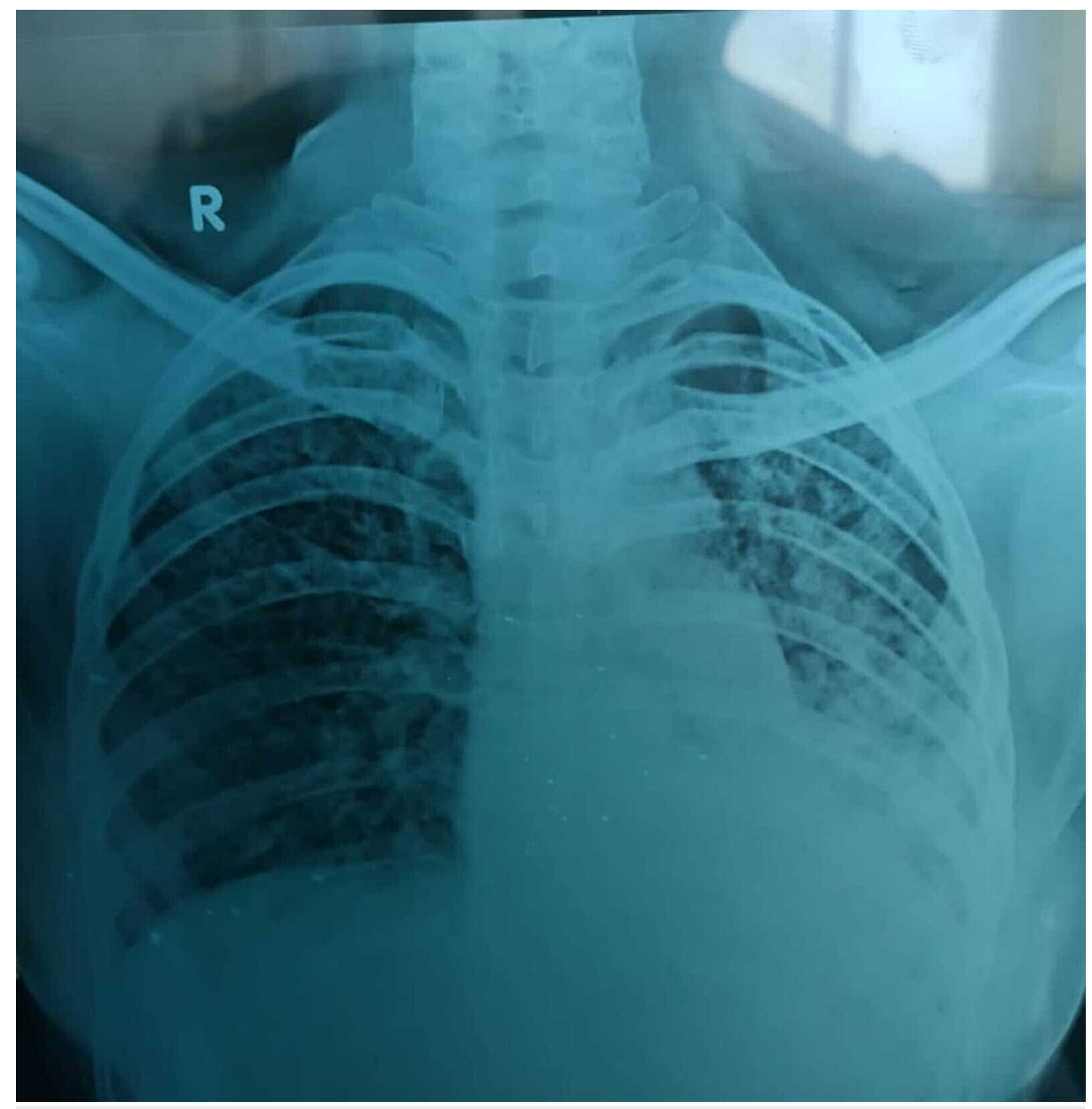

\section{FIGURE 1: Chest radiograph on day one of admission}

Chest radiograph shows left lower lobe haziness, enhanced bronchovascular markings, and multiple patchy consolidations.

High-resolution computed tomography of the thorax revealed extensive ground-glass opacity with pneumomediastinum of size $8.5 \mathrm{~mm}$ (Figure 2). 


\section{Cureus}

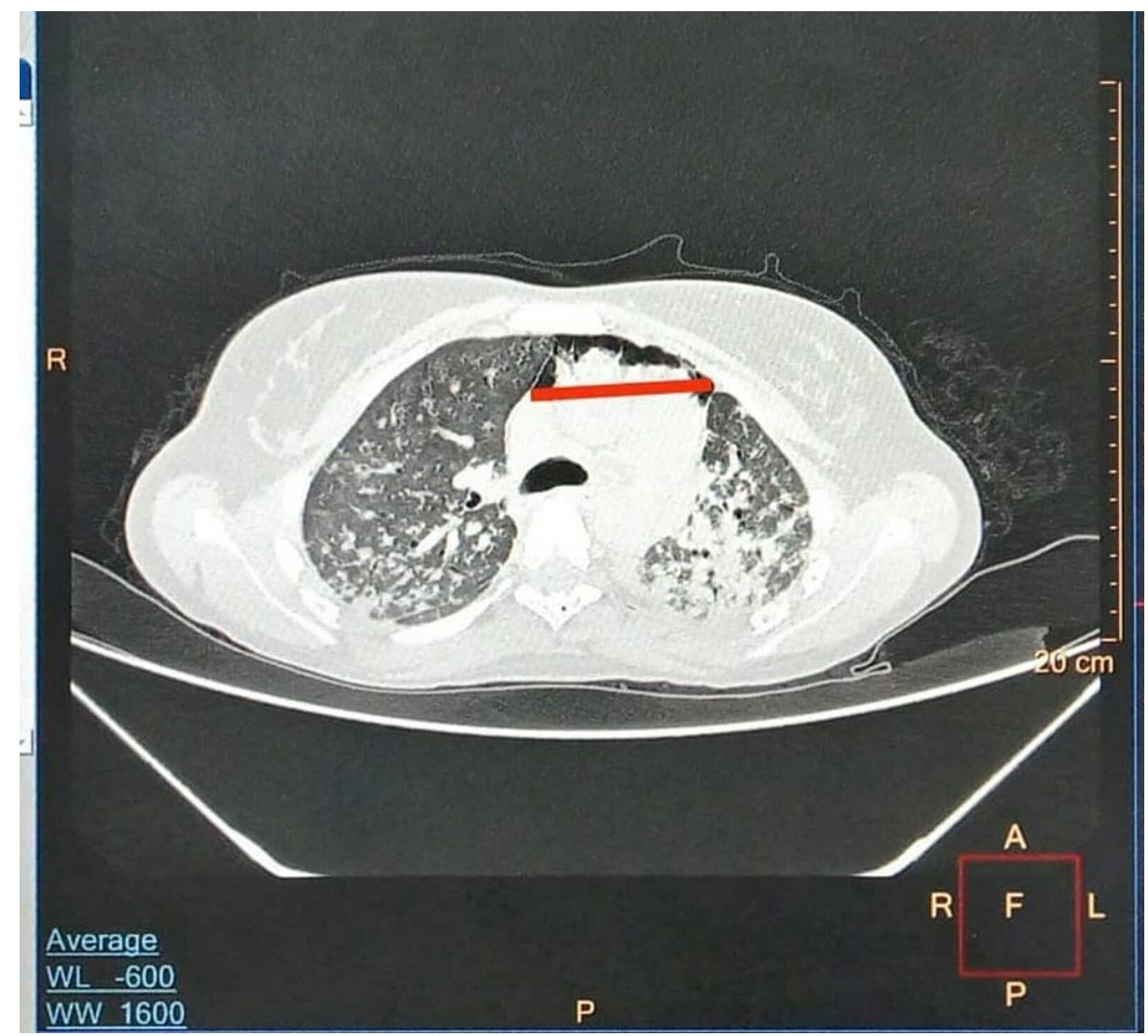

FIGURE 2: High-resolution computed tomography of the thorax

High-resolution computed tomography image of the chest showing extensive ground glass opacity with pneumomediastinum of size $8.5 \mathrm{~mm}$.

In the emergency room, the patient was started on ceftriaxone (1g twice daily), azithromycin ( $500 \mathrm{mg}$ once daily), and dexamethasone (6 $\mathrm{mg}$ thrice daily) intravenously along with oxygen titration to maintain proper saturation (85\%-88\%). N-Acetyl cysteine (dose as in case of paracetamol overdose) was given because of existing acute liver injury and inotrope support was started due to worsening mean arterial pressure. On the second day of admission, she was placed on noninvasive ventilation due to worsening respiratory distress. On day five of admission, she developed a spontaneous pneumothorax (Figure 3), and a thoracostomy tube was placed. 


\section{Cureus}

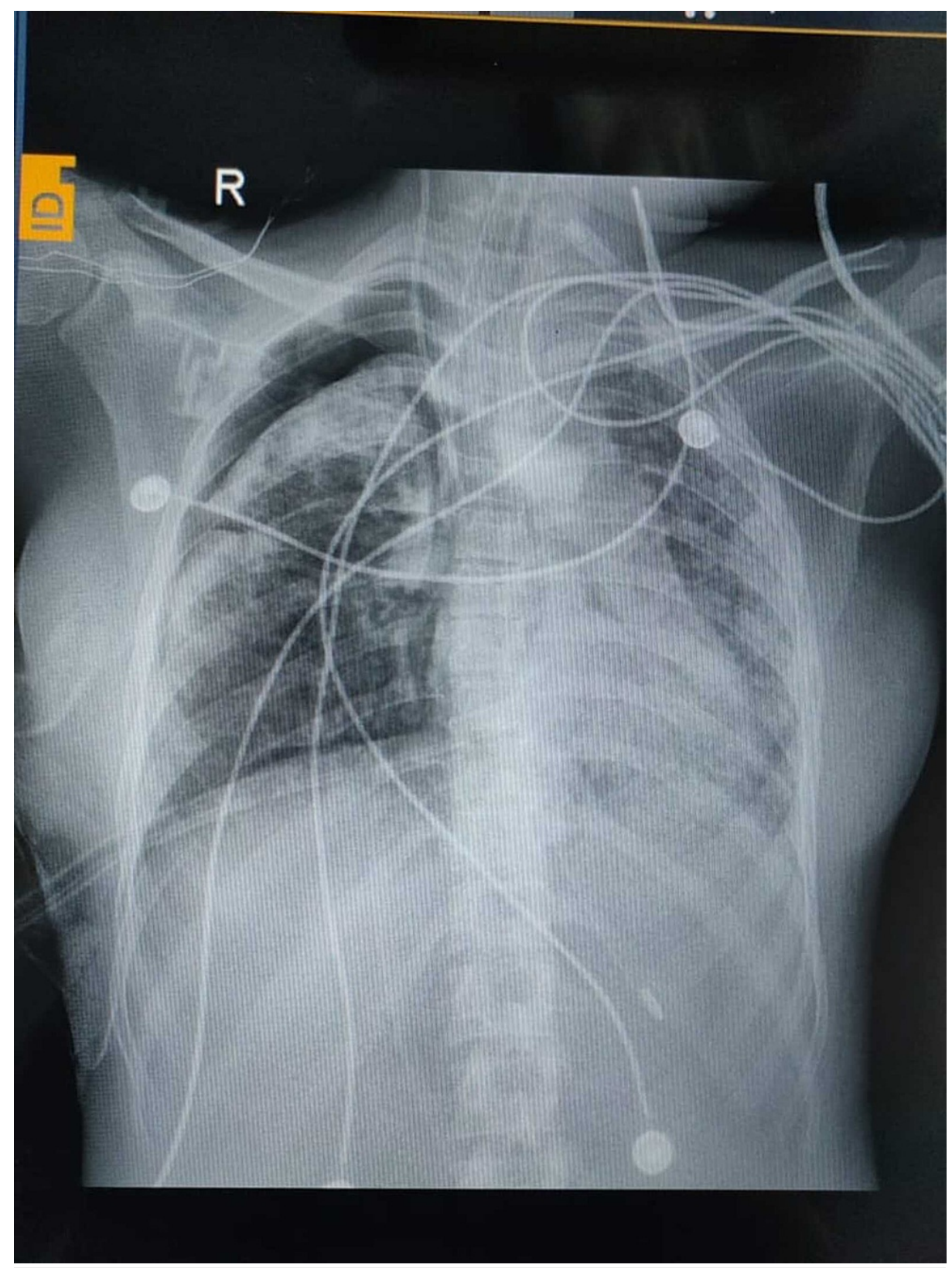

FIGURE 3: Chest radiograph on day five of admission

Chest radiograph shows right-sided pneumothorax.

On day eight, she was intubated because of increasing shortness of breath and placed on volume control mode. Procalcitonin elevated from $9.7 \mathrm{ng} / \mathrm{mL}$ (on day one) to $37.7 \mathrm{ng} / \mathrm{mL}$ (on day five); therefore, antibiotics were escalated to meropenem ( $500 \mathrm{mg}$ twice daily). Despite all efforts, the patient expired on day 17 after admission (day 29 after ingestion of paraquat).

\section{Discussion}

Paraquat was first synthesized in 1882 as a redox indicator, and later, its herbicidal properties were recognized in the 1950s [7]. The first case of paraquat-related systemic toxicity was reported in 1966 and is a common cause of herbicide poisoning in South-East Asia, with fatality rates around 50-90\% [8,9]. Paraquat ingestion can be mild, moderate to severe, or fulminant or hyperacute with corresponding doses of less than 20-30 mg, more than 20-30 mg but less than $40-50 \mathrm{mg}$, and more than 40 to $55 \mathrm{mg}$ paraquat ion per kilogram of body weight, respectively $[7,10]$. In our case, there was poisoning with a fulminant amount of paraquat poisoning.

In 1990, Daisley and Barton first described pneumothorax and pneumomediastinum induced by paraquat poisoning. The mechanism of Daisley Barton Syndrome is an initiation of pathological repair at the alveolar 
level with interstitial widening, congestion of the alveoli, deposition of collagen, and microthrombi formation leading to secondary pulmonary hypertension, a consequence of paraquat-induced pneumothorax and pneumomediastinum [6]. Damage to type 1 pneumocytes impairs oxygenation and capillary exchange, whereas type 2 pneumocyte damage leads to increased surface tension and fluid accumulation, causing pulmonary edema and hemorrhage $[11,12]$. Pneumomediastinum may be caused by corrosion and esophageal perforation due to the corrosive effect of paraquat or by air leakage from ruptured alveoli along with peribronchial vascular structures [2]. In our case, there was pneumomediastinum of size $8.5 \mathrm{~mm}$ initially and later, pneumothorax.

Early management of paraquat poisoning is essential to prevent further absorption and gastric decontamination. We avoided gastric lavage due to the corrosive nature of the poison. Activated charcoal (1$2 \mathrm{~g} / \mathrm{kg}$ ) and Fuller's earth (1-2g/kg) with 70\% sorbitol are generally used for gastric decontamination [13]. However, there is no specific antidote for paraquat poisoning. Other treatment modalities include high dose vitamin $\mathrm{C}$ or $\mathrm{E}, \mathrm{N}$-acetyl cysteine, corticosteroids, cytotoxic agents like cyclophosphamide and azathioprine [7]. We used antibiotics, corticosteroids, and $\mathrm{N}$-acetyl cysteine for treating the patient. Patients with paraquat poisoning will be harmed by supplemental oxygen due to free radical formation [9]. Therefore, it is best to avoid oxygen supplementation unless hypoxemic and target saturation is $85 \%-88 \%$, as was done for treating our patient [14]. Hemodialysis and hemofiltration are uncommon, but allow a longer duration of continuous removal for two to five days [15]. A bedside semi-quantitative test using bicarbonate and sodium dithionite can be used to confirm systemic paraquat toxicity [9].

\section{Conclusions}

Severe paraquat poisoning is associated with a poor prognosis, and there is no specific treatment associated with its ingestion. Pneumomediastinum is an early predictor of mortality in patients with paraquat poisoning, associated with $100 \%$ mortality, especially within the first eight days. Sodium dithionite can be used as a good predictor of outcome in paraquat poisoning. Additionally, oxygen should be used only if hypoxemic. Early initiation of treatment and retarding the progress of poisoning offers the only chance of survival in patients with paraquat poisoning.

\section{Additional Information \\ Disclosures}

Human subjects: Consent was obtained or waived by all participants in this study. Conflicts of interest: In compliance with the ICMJE uniform disclosure form, all authors declare the following: Payment/services info: All authors have declared that no financial support was received from any organization for the submitted work. Financial relationships: All authors have declared that they have no financial relationships at present or within the previous three years with any organizations that might have an interest in the submitted work. Other relationships: All authors have declared that there are no other relationships or activities that could appear to have influenced the submitted work.

\section{References}

1. Gupta N, Chugh A, Kanwar BS, Lamba BMS: A case report of paraquat poisoning. J Indian Acad Clin Med. 2018, 19:210-211.

2. Samsamshariat S, Vedaei A, Jahangiri S, Gavarti MB, Sami R, Taheri A, Dorooshi G: Report of a case of paraquat poisoning and mediastinal involvement. Adv Biomed Res. 2021, 10:5. 10.4103/abr.abr_95_20

3. Yen TH, Lin JL, Lin-Tan DT, Hsu CW, Weng CH, Chen YH: Spectrum of corrosive esophageal injury after intentional paraquat ingestion. Am J Emerg Med. 2010, 28:728-33. 10.1016/j.ajem.2009.06.001

4. Klein-Schwartz W, Smith GS: Agricultural and horticultural chemical poisonings: mortality and morbidity in the United States. Ann Emerg Med. 1997, 29:232-238. 10.1016/S0196-0644(97)70274-9

5. Zhou CY, Kang X, Li CB, et al.: Pneumomediastinum predicts early mortality in acute paraquat poisoning . Clin Toxicol (Phila). 2015, 53:551-6. 10.3109/15563650.2015.1046183

6. Daisley H, Barton EN: Spontaneous pneumothorax in acute paraquat toxicity. West Indian Med J. 1990, 39:180-5.

7. Sittipunt C: Paraquat poisoning. Respir Care. 2005, 50:383-5.

8. Bullivant CM: Accidental poisoning by paraquat: report of two cases in man . Br Med J. 1966, 1:1272-3. 10.1136/bmj.1.5498.1272

9. Gawarammana IB, Buckley NA: Medical management of paraquat ingestion. Br J Clin Pharmacol. 2011, 72:745-57. 10.1111/j.1365-2125.2011.04026.x

10. Chaudhuri S, Sagar M, Ravindranath S, Reddy V.: Paraquat poisoning presenting as the "Daisley Barton syndrome”. Indian J Respir Care. 2020, 9:110.

11. Sahoo D, Kar N, Devi S, Dey A, Das DS: A case of paraquat poisoning presenting with spontaneous pneumothorax and pneumomediastinum. Cureus. 2020, 12:e11943. 10.7759/cureus.11943

12. Macklin CC: Transport of air along sheaths of pulmonic blood vessels from alveoli to mediastinum: clinical implications. Arch Intern Med (Chic). 1939, 64:913-26. 10.1001/archinte.1939.00190050019003

13. Okonek S, Setyadharma H, Borchert A, Krienke EG: Activated charcoal is as effective as fuller's earth or bentonite in paraquat poisoning. Klin Wochenschr. 1982, 60:207-10. 10.1007/BF01715588

14. O'Driscoll BR, Howard LS, Earis J, Mak V: British Thoracic Society Guideline for oxygen use in adults in healthcare and emergency settings. BMJ Open Respir Res. 2017, 4:e000170. 10.1136/bmjresp-2016-000170

15. Bismuth C, Garnier R, Baud FJ, Muszynski J, Keyes C: Paraquat poisoning. An overview of the current status . 


\section{Cureus}

Drug Saf. 1990, 5:243-51. 10.2165/00002018-199005040-00002 